\title{
DINAR DIRHAM: \\ PROBLEMATIKA MATA UANG SOLUSI DI TENGAH KRISIS
}

\section{Diana Ambarwati}

Institut Agama Islam Negeri Metro Lampung

Diana.ambarwati29@gmail.com

\begin{abstract}
The getting worse of domestic currency, the more people will speculate on the system of currency usage. It will appear parties argue that the currency usage is no longer relevant in today's monetary sistem. The phenomenon then become a strong reason to impost bi-metal currency which are gold dinar and silver dirham.

In this article, presented problematics of imposing bi-metal currency, which is dinar dirham -- that can be used as solution in the midst of economic crisis or precisely it will lead to a new polemic. Finally, it was found that the dinar and dirham can not be the absolute solution to handle currency crisis. Because, the limited availability of gold become the greatest obstacle, less simple, and can be the trigger of crime. Besides that, crisis problem is not merely currency problem, but payment balance, interrelation of foreign transaction in which the economic condition of other countries as partners.
\end{abstract}

Keywords: Dinar, Dirham, Solutions, Crisis 


\section{Abstrak}

Semakin terpuruknya nilai mata uang domestik, maka akan semakin banyak yang berspekulasi tentang sistem penggunaan mata uang. Muncullah pihak-pihak yang mensinyalir, jika penggunan mata uang, sudah tidak lagi relevan dengan kondisi sistem moneter yang kekinian. Fenomena tersebut yang kemudian menjadi alasan kuat untuk kembali memberlakukan mata uang dwi logam yakni dinar emas dan dirham perak.

Dalam artikel ini ditampilkan problematika pemberlakuan mata uang dwi logam, yaitu dinar dirham-dapat dijadikan solusi di tengah-tengah krisis ekonomi atau justru akan memunculkan polemik baru. Akhirnya, ditemukan jawaban bahwa dinar dan dirham tidak secara mutlak dapat menjadi solusi atas krisis yang terjadi. Sebab, ketersediaan emas yang terbatas menjadi kendala terbesar, kurang praktis, dan dapat memicu kejahatan. Selain itu, persoalan krisis bukan semata-mata persoalan mata uang tetapi keseimbangan neraca pembayaran, keterkaitan transaksi luar negeri yang kondisi ekonomi negara lain sebagai mitra.

Keywords: Dinar, Dirham, Solusi, Krisis 


\section{A. PENDAHULUAN}

$\mathrm{K}$

risis ekonomi pada tahun 1997 yang melanda negara Indonesia dan sebagian besar negara-negara yang ada di nilai mata uang domestik dalam menghadapi "kedigdayaan" mata uang asing-khususnya Dolar AS. Munculnya krisis ini juga tidak hanya dipicu oleh persoalan nilai tukar semata, akan tetapi di sebabkan pula oleh adanya suatu pergeseran fungsi uang dari track-nya. Uang tidak hanya sekadar menjadi alat tukar, namun uang telah memiliki predikat dan fungsi lain, yakni untuk maraup keuntungan. Sebagaimana yang telah di kemukakan Darwis, bahwa krisis moneter yang terjadi pada dasarnya disebabkan fungsi uang tidak lagi hanya sebagai alat tukar dan alat untuk berjaga-jaga (precautionary motive), akan tetapi telah beralih fungsi menjadi kegiatan spekulatif, yang tujuannya untuk mencari keuntungan pada saat nilai tukar rupiah melemah terhadap Dolar AS. ${ }^{1}$

Kemudian, menurut Yusanto, krisis ekonomi ini semakin berlanjut ketika uang digunakan sebagai komoditas. Uang telah menjadi barang yang dapat di perdagangkan dan pada akhirnya setiap orang dapat mengambil keuntungan dari transaksi tersebut. $^{2}$ Memperhatikan uraian tersebut, munculnya krisis ekonomi yang melanda negara ini dan negara-negara lainnya di kawasan Asia, merupakan dampak dari bergesernya fungsi utama dari uang sebagai alat tukar (medium of exchange) ${ }^{3}$ di tengah-tengah masyarakat.

Semakin terpuruknya nilai mata uang domestik, maka akan semakin banyak yang berspekulasi tentang sistem penggunaan mata uang sebagaimana yang telah berlaku. Muncullah pihak-pihak yang mensinyalir, jika penggunan mata uang, sudah tidak lagi relevan

1 Darwis Harahap, Analisis Stabilitas Dinar Emas Dan Dolar AS Dalam Denominasi Rupiah, dalam Jurnal Al-Iqtishad, Vol. VI, No. 2, Juli 2014, h. 270.

2 Muhammad Ismail Yusanto dkk, Dinar Emas, Solusi Moneter, (Jakarta: Pirac, Sem Institut, Infid, 2001), h.2

3 Meski pada akhirnya muncul turunan fungsi-fungsi lain dari fungsi utama tersebut, yaitu uang sebagai standard of value, store of value, unit of account dan standard of deferred payment. Lihat dalam Santi Endriani, "Konsep Uang: Ekonomi Islam vs Ekonomi Konvensional”, Anterior Jurnal, Volume 15 Nomor 1, Desember 2015, h. 71. 
dengan kondisi sistem moneter yang kekinian. Fenomena tersebut yang kemudian menjadi alasan kuat untuk kembali memberlakukan mata uang dwi logam yakni dinar emas dan dirham perak.

Gagasan awal gerakan ini dilakukan pada suatu konferensi pada bulan Agustus 2002 yang mengankat tema: "Stable and Just Globar Monetary System menghasilkan penerapan Dinar emas pada transaksi perdagangan luar negerinya dengan mitra dagang melalui Pengaturan Pembiayaan Bilateral (Billateral Payment Arrangement) atau BPA. Gagasan tersebut dilanjutkan pada seminar di Kuala Lumpur tanggal 22-23 Oktober 2002 dengan tema: "Te Gold Dinar in Multilateral Trade" dengan menyetujui usulan Kepala Bank Sentral Iran, untuk membentuk suatu sekretariat yang ditugasi mengkoordinir pengembangan kebijaksanaan Dinar Islami. ${ }^{4}$

Istilah standar emas (return to a gold standard) merujuk pada gagasan untuk mengembalikan sistem peredaran mata uang (the supply of money) yang berdasarkan pada persedian emas (the supply of gold) kepada sistem uang nyata (real money). ${ }^{5}$

Dalam kontek kekinian, penerapan atau memberlakukan mata uang dwi logam, yaitu dinar dirham-dapat dijadikan sebentuk solusi di tengah-tengah krisis ekonomi. Atau keduanya justru akan memunculkan polemik-polemik baru, mengingat negara-negara pemilik emas terbesar di dunia ini bukan negara-negara Islam. Untuk itulah tulisan ini akan mendeskripsikan tentang dinar dirham, problematika mata uang solusi di tengah krisis. Benarkah dwi logam tersebut dapat dijadikan sebuah solusi mata uang di tengah krisis ekonomi yang terjadi.

\section{B. KONSEP UANG, DINAR DAN DIRHAM DALAM KILASAN SEJARAH}

Uang adalah inovasi besar dalam peradaban perekonomian dunia. Posisi uang sangat strategis dalam sistem ekonomi dan sulit

4 Perwataatmadja, Menggagas Ekonomi Syariah Yang Mantap dengan Peraturan Perundangundangan yang Baik, Seminar Nasional Hukum Ekonomi, Senat Mahasiswa Fakultas Hukum Universitas Indonesia, tanggal 25-27 Februari 2003, Kampus UI Depok.

5 Deny Setiawan dkk, Kekuatan Emas Dan Perak Sebagai Mata Uang Dunia Suatu Studi Pendahuluan, Jumal Ekonomi Volume 18, Nomor 1 Maret 2010. 
digantikan dengan variabel lainnya. Bisa dikatakan bahwa uang merupakan bagian yang terintregasi dalam sistem ekonomi. ${ }^{6}$ Uang merupakan alat tukar standar, alat ukur nilai (kesatuan hitungan) yang sah, dikeluarkan Pemerintah suatu negara berupa uang kertas, emas, perak atau logam lain yang dibentuk dan gambar tertentu. ${ }^{7}$ Menurut Sulaiman Rasyid uang merupakan segala sesuatu yang dapat diterima oleh masyarakat umum sebagai alat tukar di dalam lalu lintas perekonomian. Sedangkan menurut jumhur fuqoha mazhab Malikiyah, Syafi'iyah dan Hanabilah adalah: "Sesuatu yang naluri manusia cenderung kepadanya dan dapat diserahterimakan dan orang lain terhalang menggunakannya". ${ }^{8}$

Berdasarkan pada definisi di atas, dapat kita ketahui bahwa setiap benda, apapun bentuk benda yang memiliki fungsi sebagai alat tukar disebut uang, dengan catatan benda tersebut dapat diterima oleh masyarakat umum sebagai alat tukar dan tidak alasan orang lain tidak menerimanya sebagi alat pembayaran. Selanjutnya ada pendapat yang menyatakan bahwa untuk menguji apakah suatu benda dapat di katakan uang adalah dengan melihat apakah benda tersebut dapat segera dibayarkan tanpa menukarnya lagi dengan barang lain dan tanpa menunggu kesediaan orang lain untuk menerimanya. ${ }^{9}$ Lebih jauh, sesuatu benda harus memenuhi beberapa syarat agar ia berfungsi sebagai uang yang baik, yaitu: Memiliki nilai tertentu, Tidak mudah rusak, Mudah dibawa, pembagian atasnya tidak merusak nilainya. ${ }^{10}$

Untuk menunjukkan uang atau fungsinya, al-Quran menggunakan beberapa istilah, antara lain dirham, dinar, emas dan perak. Kata dirham hanya disebutkan satu kali, yaitu dalam QS. Yusuf (12) ayat 20

6 Mustofa Edwin Nasution, Pengenalan Eklusif Ekonomi Islam, (Jakarta: Kencana Prenadi, 2006), h. 239.

7 Departemen Pendidikan dan Kebudayaan, Kamus Besar Bahasa Indonesia, (Jakarta: Balai Pustaka, 2001), h.1233.

8 Gufron A. Mas'adi, Fiqh Muamalah Kontekstual, (Jakarta: Rajagrafindo, 2002), h.11.

9 Suherman Rasyidi, Pengantar Teori Ekonomi Pendekatan Kepada Teori Ekonomi Mikro dan Makro, (Jakarta: Raja Grafindo Persada, 1999), h. 69.

10 Suherman Rasyidi, Pengantar Teori Ekonomi... 


$$
\text { وَشَرَوْهُ بِثَمَنِ بَخْس دَرَاهِمَ مَعْدُودَةٍ وَكَانُوا فِيهِ مِنَ الزَّاهِدِينَ }
$$

"dan mereka menjual Yusuf dengan harga yang murah, Yaitu beberapa dirham saja, dan mereka merasa tidak tertarik hatinya kepada Yusuf."11

Dalam ayat ini selain dikemukakan dirham sebagai mata uang dan fungsinya sebagai alat pertukaran, disinggung juga bahwa penggunaan dirham di kalangan masyarakat saat itu berpatokan pada jumlah atau bilangan, bukan pada nilainya.

Sebagaimana dirham, kata dinar hanya disebutkan satu kali, yaitu dalam QS. Ali Imran (3) ayat 75.

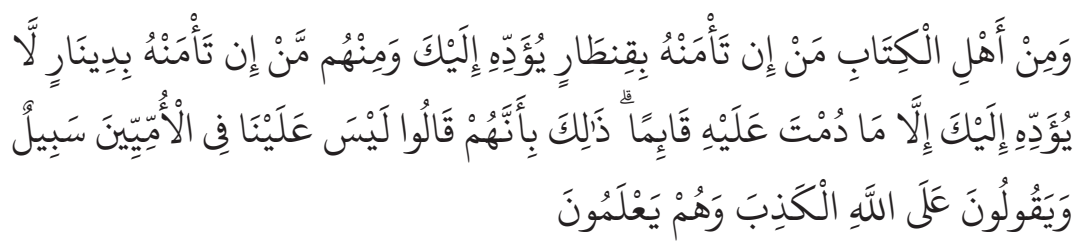

"di antara ahli kitab ada orang yang jika kamu mempercayakan kepadanya harta yang banyak, dikembalikannya kepadamu; dan di antara mereka ada orang yang jika kamu mempercayakan kepadanya satu dinar, tidak dikembalikannya kepadamu kecuali jika kamu selalu menagihnya. yang demikian itu lantaran mereka mengatakan: «tidak ada dosa bagi Kami terhadap orang-orang ummi. mereka berkata Dusta terhadap Allah, Padahal mereka mengetahui." ${ }^{22}$

Ayat ini, selain menyebutkan dinar sebagai satuan mata uang tertentu untuk pengukur nilai, mengisyaratkan pula bahwa uang adalah alat penyimpan nilai.

Mengenai kata emas dan perak cukup banyak ditemukan dalam al-Quran. Hal ini nampaknya disebabkan ketika al-Quran diturunkan masyarakat banyak menggunakan emas dan perak dalam melakukan kegiatan transaksi. Emas disebutkan pada delapan tempat; di antaranya QS. al-Taubah (9) ayat 34,

11 QS. Yusuf ayat 20. Hati mereka tidak tertarik kepada Yusuf karena Dia anak temuan dalam perjalanan. Jadi mereka kuatir kalau-kalau pemiliknya datang mengambilnya. oleh karena itu mereka tergesa-gesa menjualnya Sekalipun dangan harga yang murah

12 QS. Ali Imran (3) ayat 75. Yang mereka maksud dengan orang-orang Ummi dalam ayat ini adalah orang Arab. 


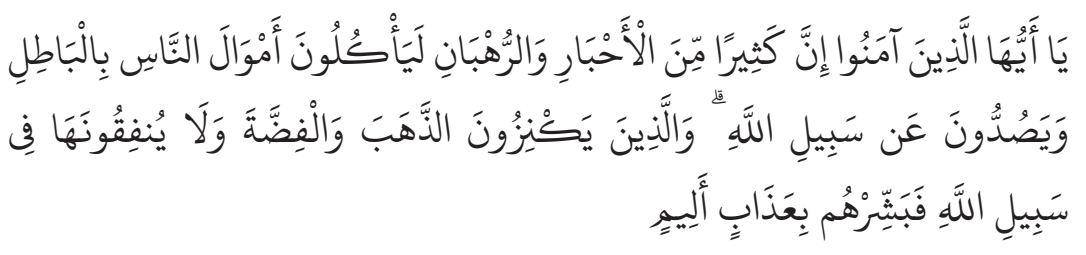

"Hai orang-orang yang beriman, Sesungguhnya sebahagian besar dari orang-orang alim Yahudi dan rahib-rahib Nasrani benar-benar memakan harta orang dengan jalan batil dan mereka menghalanghalangi (manusia) dari jalan Allah. dan orang-orang yang menyimpan emas dan perak dan tidak menafkahkannya pada jalan Allah, Maka beritahukanlah kepada mereka, (bahwa mereka akan mendapat) siksa yang pedih."13

Selain mengandung isyarat bahwa emas dan perak adalah satuan mata uang, alat pembayaran dan penyimpan nilai, ayat ini mengandung larangan penimbunan uang karena akan berakibat mematikan, fungsinya sebagai sarana kegiatan ekonomi.

Ayat lain yang menyebutkan emas sebagai mata uang dan alat pertukaran adalah QS. Ali Imran (3) ayat 91,

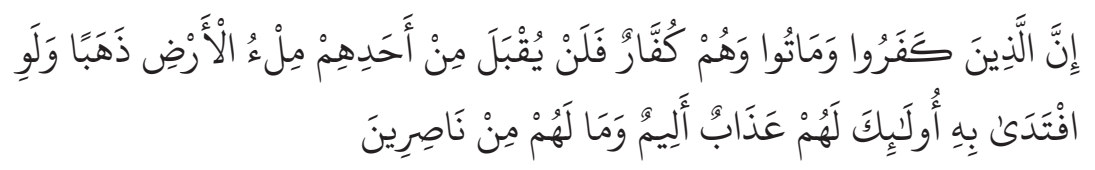

"Sesungguhnya orang-orang yang kafir dan mati sedang mereka tetap dalam kekafirannya, Maka tidaklah akan diterima dari seseorang diantara mereka emas sepenuh bumi, walaupun Dia menebus diri dengan emas (yang sebanyak) itu. bagi mereka Itulah siksa yang pedih dan sekali-kali mereka tidak memperoleh penolong."14

Sementara itu, kata perak disebutkan enam kali dalam alQuran. Di antaranya adalah QS. Ali Imran (3) ayat 14,

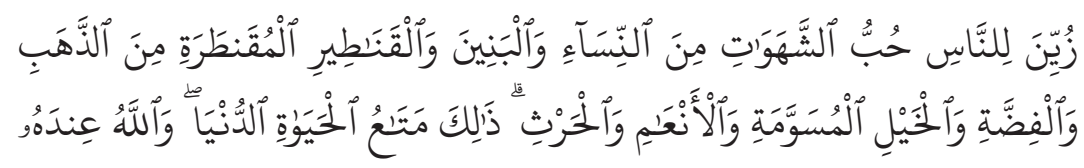

13 QS. al-Taubah (9) ayat 34

14 QS. Ali (3) ayat 91 


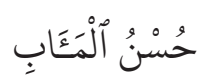

"dijadikan indah pada (pandangan) manusia kecintaan kepada apa-apa yang diingini, Yaitu: wanita-wanita, anak-anak, harta yang banyak dari jenis emas, perak, kuda pilihan, binatang-binatang ternak dan sawah ladang. Itulah kesenangan hidup di dunia, dan di sisi Allah-lah tempat kembali yang baik (surga)."15

Selain itu juga terdapat dalam QS. al-Kahf (18) ayat 19,

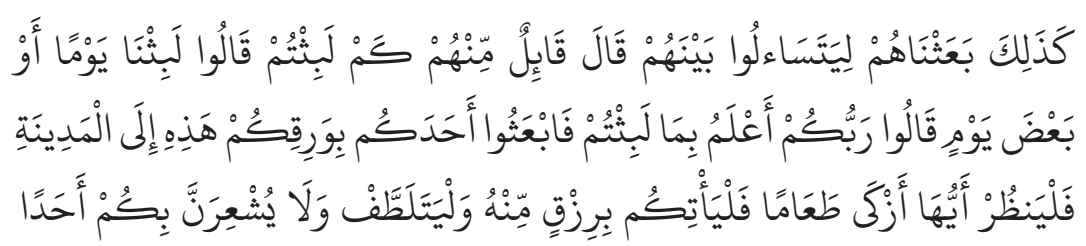
"dan Demikianlah Kami bangunkan mereka agar mereka saling bertanya di antara mereka sendiri. berkatalah salah seorang di antara mereka: sudah berapa lamakah kamu berada (disini?)". mereka menjawab: "Kita berada (disini) sehari atau setengah hari". berkata (yang lain lagi): "Tuhan kamu lebih mengetahui berapa lamanya kamu berada (di sini). Maka suruhlah salah seorang di antara kamu untuk pergi ke kota dengan membawa uang perakmu ini, dan hendaklah Dia Lihat manakah makanan yang lebih baik, Maka hendaklah ia membawa makanan itu untukmu, dan hendaklah ia Berlaku lemah-lembut dan janganlah sekali-kali menceritakan halmu kepada seorangpun."16

Dalam surat al-Kahf ini, kata perak tidak disebut dengan fidhdhah sebagaimana dalam ayat-ayat lain,tetapi dengan kata wariq, yaitu perak yang dicetak dan dijadikan uang.

Sejak zaman Nabi SAW hingga Dinasti Ustmaniyah, hanya dikenal uang emas dan perak, uang kertas tidak dikenal sama sekali. Sebenarnya mata uang ini dibentuk dan dicetak oleh Julius Caesar dari kekaisaran Romawi. Secara bahasa, dinar berasal dari kata Denarius (Romawi Timur) dan dirham berasal dari kata Drachma

15 QS. Ali Imran (3) ayat 14. Yang dimaksud dengan binatang ternak di sini ialah binatangbinatang yang Termasuk jenis unta, lembu, kambing dan biri-biri

16 QS. al-Kahf (18) ayat 19 
(Persia). ${ }^{17}$ Dinar romawi dan dirham persialah yang dahulu di pakai oleh rasulullah untuk bertransaksi.

Pada masa rasulullah tidak pernah mencetak dinar dan dirham sendiri. ${ }^{18}$ bahkan sepanjang kehidupannya Nabi SAW tidak pernah merekomendasikan perubahan apapun terhadap mata uang, artinya Nabi SAW dan para sahabat yang menjadi khalifah sesudahnya membenarkan praktek ini. standarisasi berat uang dinar dan dirham mengikuti hadist Rasululah SAW, 'timbangan adalah timbangan penduduk Makkah, dan takaran adalah takaran penduduk Madinah'. ${ }^{19}$ Baru pada tahun $79 \mathrm{M}$ masa khalifah Abdul Malik Bin Marwan dicetak dinar dan dirham khusus dengan lafad Islam yang khas. ${ }^{20}$ Uang dinar yang dipergunakan adalah setara 4,25 gram emas 22 karat dengan diameter 23 milimeter. Standar ini telah ditetapkan pada masa Rasulullah dan dipergunakan oleh World Islamic Trading Organization (WITO) hingga saat ini. Sedangkan uang Dirham setara dengan 2.975 gram perak murni. Dinar dan Dirham adalah mata uang yang berfungsi sebagai alat tukar baik sebelum datangnya Islam maupun sesudahnya. ${ }^{21}$

Dinar dan dirham bukanlah mata uang tunggal atau mata uang resmi orang Islam atau di negara Islam. Sebelum kemudian disahkan oleh Rasul sebagai mata uang yang sah dalam dunia Islam, dinar dan dirham adalah mata uang yang digunakan oleh bangsa Roma dan Persia. Dinar Roma telah banyak beredar di kalangan penduduk Mekkah, begitu pula halnya dengan dirham Persia. Bangsa Arab menyebut uang emas pada saat itu dengan istilah alAin, sedangkan uang perak disebut al-Wariq. ${ }^{22}$

Fungsi dinar dan dirham, sebagai uang merupakan; pertama, satuan hitung. Tujuan utama diciptakan uang oleh manusia adalah

17 Muhaimin Iqbal, Dinar The Real Money: Dinar Emas, Uang Dan Investasiku, (Jakarta: Gema Insani Press). h. 29-30.

18 Nurul Huda, Ekonomi Makro Islam Pendekata Teoritis, (Jakarta: Kencana Persada Media Group, 2008), h. 99

19 Muhaimin Iqbal, Dinar The Real Money..., h. 29-30.

20 Muhammad Ismail Yusanto dkk, Dinar Emas, Solusi Moneter, (Jakarta: Pirac, Sem Institut, Infid, 2001), h.14

21 Nurul Huda, Ekonomi Makro Islam..., h. 99.

22 Adiwarman A Karim, Ekonomi Makro Islami, (Jakarta: PT Rajagrafindo Persada, 2007) 
sebagai perantara yang digunakan sebagai alat ukur dan satuan hitung. Kedua, uang sebagai alat penyimpan nilai. Pada dasarnya manusia adalah makhluk yang gemar mengumpulkan dan menyimpan kekayaan dalam bentuk barang-barang berharga yang dipergunakan untuk masa yang akan datang. Ketiga, uang Sebagai Media Tukar. Uang adalah sesuatu zat yang tidak ada harganya kecuali nilai uang itu sendiri dan dengan nilai tersebutlah bisa mendapatkan sesuatu yang dibutuhkan secara adil. Keempat, uang sebagai ukuran pembayaran tertunda. Fungsi ini terkait dengan transaksi pinjam-meminjam, uang merupakan salah satu cara untuk menghitung jumlah pembayaran pinjaman tersebut. ${ }^{23}$

Gresham's menyatakan bahwa “ bad money tends to drive good money out of transaction" artinya uang yang nilainya turun akan mendesak uang yang nilainya naik, dan inilah kemudian dikenal dengan nama hukum Gresham. Hukum ini hanya berlaku pada negara-negara yang menerapkan standar kembar atau bimetallism. Standar kembar ini adalah kebijakan standar moneter yang berdasarkan pada dua logam, yakni emas dan perak sebagai alat pembayaran yang sah. ${ }^{24}$ Dengan demikian orang akan cenderung menggunakan uang lusuh sehingga mengakibatkan uang yang masih baik keluar dari peredaran. ${ }^{25}$

\section{UPAYA PEMBERLAKUKAN DINAR DAN DIRHAM DI BEBERAPA NEGARA}

Banyak ilmuwan yang telah menulis artikel ilmiah yang mengulas tentang kemungkinan kembali menerapkan dinar dan dirham sebagai mata uang yang resmi sebuah negara. Di Indonesia, Zaim Saidi merupakah salah satu tokoh yang sangat gencar menyuarakan kembali ke dinar dan dirham. Bahkan Umar Ibrahim Vadillo merumuskan kerangka dan mekanisme implementasi dinar dan dirham di suatu negara.

23 Ahmad Hasan, Mata Uang Islami: Telaah Komprehensif Sistem Keuangan Islami, (Jakarta: Rajagrafindo Persada). h. 5.

24 Wikipedia .org

25 Kamus Bisnis dan Bank, dalam www.mediabpr.com 
Yang menarik adalah bahwa pemberlakuan kembali dinar dan dirham ini bukan hanya pada tataran pemikiran tetapi telah sampai pada tataran praktek, walau sifatnya masih terbatas. Misalnya tahun 2018 media diramaikan dengan pemberitaan tentang Gubernur Arizona (salah satu negara bagian Amerika Serikat) yakni Doug Ducey yang menandatangani House Bill 2014 (HB2014) tanggal 22 Mei 2017, dengan ditandatanganinya HP-2014 ini adalah sebagai penanda mulai diperbolehkannya warga Arizona menggunakan logam mulia menjadi mata uang. ${ }^{26}$

Zaim Saidi juga mengutip, Rengky yasepta seorang penggerak komunitas melek dinar dan dirham, dalam USmoneyreserve.com mengatakan bahwa ada 8 (delapan) negara bagian di Amerika Serikat yang sedang membahas dan akan mengesahkan Undangundang tentang legalisasi emas dan perak sebagai mata uang di negara tersebut. Negara yang dimaksud adalah Arizona, Idaho, Texas, Utah, Wyoming, Tennessee, Kansas dan Louisiana. ${ }^{27}$

Demikian juga praktek pemberlakuan dinar dirham juga dilakukan di Indonesia. secara non formal penggunaan dinar dan dirham telah dilakukan di beberapa kota, yakni kepualaun riau, kota Medan, Solo. Berita ini penulis temukan pada website wakalaindukbintan.com. dalam berita tersebut dinyatakan bahwa di Medan telah berlaku pembayaran transaksi jilbab, gamis, mukena, tas dan Lunchset di toko dhansa Shop milik ibu Anintya. Demikian jamu organic di Medan juga dapat dibayar dengan mengunakan dirham. Membeli VCO di kepulauan Riau. Demikian juga dengan mahar menggunakan dirham. Dirham yang dimaksud adalah koin perak murni seberat 2.975 gram yang dikeluarkan para Sultan seperti Kesultanan Bintan Darul Masyhur, Kemangkunegrian Ketapang, Kesultanan Cirebon, Kesultanan Ternante, Kesultanan Sulu dan Amirat Indonesia. ${ }^{28}$ Bank Bank Indonesia (BI) juga mencetak dan mengeluarkan berbagai jenis uang logam emas. Ini

26 Zaim Saidi, Delapan Negara Bagian AS Menuju Berlakukan Uang Emas dan Perak, diakses pada https://zaimsaidi.com/delapan-negarabagian-berlakukan-emas-perak/.

27 Zaim Saidi, Delapan Negara Bagian AS Menuju Berlakukan Uang Emas dan Perak, diakses pada https://zaimsaidi.com/delapan-negarabagian-berlakukan-emas-perak/.

28 http://wakalaindukbintan.com/jasa-kurir-dibayar-dirham-di-medan 
merupakan salah satu jenis uang khusus milik BI. Uang logam emas BI ini dibuat khusus dengan bahan dasar emas dan dijadikan sebagai koleksi. ${ }^{29}$

Dalam konteks Indonesia, pemberlakuan ini merupakan upaya personal dan kelompok untuk kembali menggunakan mata uang yang digunakan pada masa Rasulullah, dan merupakan spirit kecintaan mereka pada Rasulullah. Walau sifatnya masih terbatas tapi gerakan ini untuk beberapa kalangan dan kelompok mulai berkembang. Walau secara umum tidak mendapatkan respon baik dari masyarakat umum yang menilai pemberlakuan dinar dan dirham merupakan langkah mundur. Mengingat semakin majunya alat pembeyaran kini yang juga mulai meninggalkan alat tukar fisik menuju alat tukar digital.

Demikian di Malaysia juga telah banyak tulisan ilmiah yang mendorong pemerintah untuk memberlakukan mata uang dinar dan dirham dan kemungkinannya mengatasi krisis ekonomi yang terjadi di Asia. Sebagaimana implementation gold dinar: is it feasible? Yang ditulis oleh siti Zaiton binti Moh Dali dkk, dalam artikelnya ia mengataakan bahwa pemberlakuan gold dinar tidak bisa dipungkiri hanya tinggal menunggu respon pemerintah untuk mengesahkan. Namun demikian berbeda denga artikel abu Bakar Mohd Yusuf dalam artikelnya implementation of gold dinar: is it the end of speculatative measurement dan menyimpulkan bahwa pemberlakukan dinar tidak mengakhiri tindakan spekulati, tetapi akan muncul spekulasi baru dengan cara menahan dinar dan menarik dari pasaran. Sehingga mengakibatkan hilangnya dinar dari peredaran dan tinggalah mata uang lain yang beredar di masyarakat. ${ }^{30}$

Dalam sejarah Islam juga dinyatakan bahwa memang benar Rasulullah menggunakan dinar dan dirham sebagai alat tukar, namun demikian rasulullah tidaklah mencetak uang emas dan perak sendiri. Artinya rasulullah menerima dan menggunakan

29 Mengintip Koleksi Uang Logam Emas Milik BI, dalam https://finance. detik.com/moneter, Selasa, 16 Feb 2016.

30 siti Zaiton binti Moh Dali dkk, implementation gold dinar: is it feasible?, PROSIDING PERKEM VIII, JILID 3 (2013), h. 1272 - 1279. 
mata uang yang berasal dari negara lain. Artinya rasulullah bersifat sangat terbuka dan egaliter. Demikian pula rasulullah tidak pernah menolak mata uang lain sebagai alat tukar dalam transaksi yang dialakukan. Dengan demikian penggunaan dinar dan dirham merupakan sunah nabi yang harus diikuti umatnya.

\section{DINAR DAN DIRHAM: KELEBIHAN DAN KELEMAHANNYA SEBAGAI MATA UANG}

Untuk melihat seberapa besar kemungkinan efektifitas dari pemberlakuan dinar dan dirham guna mengatasi kondisi krisis, maka mari kita telaah pendapat para ahli berkaitan dengan kelebihan atau keunggulan dinar dan dirham sebagai mata uang. Dalam sebuah tulisan Euis Amalia seorang dosen Ekonomi Islam di Universitas Islam Negeri Jakarta menyatakan bahwa dinar dan dirham akan lebih banyak digunakan untuk melakukan transaksi dalam skala besar seperti perdagangan luar negeri dan transaksi domestik lainnya. ${ }^{31}$ Demikian Nurul Huda dalam bukunya Ekonomi Makro Islam Pendekatan Teoritis mengungkapkan bahwa penggunaan dinar dalam perdagangan internasional akan memberikan berbagai keuntungan, ${ }^{32}$ diantaranya, pertama, penggunaan dinar mengurangi dan menghapus resiko nilai tukar. ${ }^{33}$ Kehadiran uang dinar akan menghapus setiap resiko yang ditimbulkan dari nilai tukar karena dinar adalah mata uang yang stabil dan menguntungkan bagi setiap negara yang melakukan perdagangan, walaupun harga nilai emas berfluktuasi, tetapi tingkat perubahannya lebih kecil dibandingkan dengan tingkat fluktuasi uang kertas.

Kedua, penggunaan dinar akan mengurangi terjadinya spekulasi, manipulasi, dan arbitrasi terhadap mata uang nasional. Ketika tiga negara, seperti Malaysia, Indonesia, dan Brunei Darussalam melakukan perdagangan maka akan ada tiga jenis mata uang. Tetapi dengan menjadikan dinar sebagai mata uang tunggal dalam perdagangan, maka tidak akan ada spekulasi atau arbitrasi

31 Euis Amalia, Sejarah Pemikiran Ekonomi Islam dari Masa Klasik Hingga Kontemporer, (Jakarta; Pustaka Asatruss, 2005), h. 222.

32 Nurul Huda, Ekonomi Makro Islam..., h.118-119.

33 Ibid. 
yang terjadi dalam perdagangan tersebut. Pada prakteknya, situasi ekonomi dan politik sebuah negara akan mempengaruhi nilai tukar mata uangnya dan akan berpengaruh pada pasar dan aktivitas ekonomi, tetapi dengan dinar sebagai mata uang global, hal tersebut tidak akan berpengaruh signifikan karena dinar bukan milik suatu negara tertentu. ${ }^{34}$ Walaupun pendapat ini dibantah oleh Abu Bakar Bin Mohd Yusuf dkk mempertanyakan apakah dengan digunakannya dinar dan dirham menjadi akhir tindakan spekulatif. Dalam tulisannya ia menjawab bahwa dinar dan dirham pun tidak menjamin para spekulan akan berakhir. Lebih lanjut ia menyatakan bahwa dengan diberlakukannya dinar dan dirham akan menjadikan para spekulan rakus akan mengubah taktik dengan berspekulasi pada harga emas untuk mendapatkan untung. ${ }^{35}$

Ketiga, penggunaan dinar akan mengurangi biaya transaksi perdagangan (Transaction Cost) dan meningkatkan perdagangan. ${ }^{36}$ Jumlah uang dinar yang sedikit akan bisa menutupi transaksi dalam jumlah besar serta memberikan peluang kepada negara yang tidak memiliki cadangan devisa yang cukup sekalipun. Keempat, penggunaan uang dinar dalam perdagangan akan meningkatkan perdagangan yang pada akhirnya akan meningkatkan kerjasama antarnegara peserta. Kelima, penggunan uang dinar dalam perdagangan internasional akan mengurangi Sovereignty (kekuasaan) dengan sistem perdagangan uang fiat saat ini telah memberikan peluang dan ruang kepada negara-negara maju untuk menguasai perekonomian dunia dan memperlebar jurang antara negara kaya dengan negara miskin. Penggunaan dinar akan mengurangi ketergantungan negara berkembang dan miskin terhadap perekonomian negara maju, mengingat sebagian besar sumber daya alam di dunia ini berada di negara-negara berkembang.

Hal senada juga diungkapkan M.Luthfi Hamidi dalam bukunya Gold Dinar System Moneter Global yang Stabil dan Berkeadilan ia menyatakan bahwa dampak implementasi dinar dalam perdagangan

34 Ibid.

35 Abu Bakar Bin Mohd Yusuf dkk, Implementation Of The Gold Dinar; Is It The End Of Speculative Measure?, Journal of Economic Coopration 23, 3 (2002), h. 71-84

36 Nurul Huda, Ekonomi Makro Islam..., h.118-119. 
internasional diproyeksikan akan mendatangkan banyak manfaat, yakni (1) mengurangi dampak volabilitas yang disebabkan oleh fluktuasi mata uang; (2) trader tidak perlu lagi melakukan hedging; (3) transaksi semakin efisien karena semakin banyak negara yang bergabung, hanya diperlukan dinar yang relatif kecil untuk volume perdagangan yang difasilitasi; (4) dinar akan berperan seperti mata uang bersama yang berimplikasi akan mengurangi biaya transaksi; (5) keuntungan politis dimana para pendukung dinar akan menjadi blok yang solid diperhitungkan kiprahnya. ${ }^{37}$

Dalam hal kestabilan mata uang dari hasil penelitian yang dilakukan Darwis Harahap yang berjudul analisis stabilitas dinar emas dan dolar AS dalam denominasi rupiah, bahwa setelah membandingkan nilai tukar dinar dan dollar, dihasilkan bahwa dinar memiliki kestabilan yang baik pada nilai tukar rupiah. ${ }^{38}$

Sebagaimana kelebihan yang dimiliki dinar dan dirham ketika diberlakukan di suatu negara, maka kondisi ini tak luput juga dari kelemahan. Kita ketahui saat ini tak ada satupun negara yang masih menggunakan uang emas dinar maupun dirham. Semua negara di dunia telah meninggalkan uang emas dan perak. Inggris telah meninggalkan mata uang emas sejak 1931, dan banyak negara lain juga telah meninggalkan mata uang dwi logam ini yakni emas dan perak. Tentu bukan tanpa alasan kejadian ini secara bersamaan dalam waktu tak berselang lama. Tentu ini kontradiktif dengan pernyataan Zaim Saidi yang menyatakan bahwa mata uang emas tidak memiliki kelemahan sama sekali. Jika saja mata uang ini tidak memiliki kelamahan tentu saja setiap negara pengguna mata uang emas tak akan meninggalkan mata uang ini. Namun yang terjadi adalah sebaliknya?

Beberapa ilmuwan menyatakan bahwa penggunaan emas dan perak terkendala pada bahan baku mata uang itu sendiri. Penggunaan mata uang emas tentu selalu tergantung pada ketersediaan emas. Hal ini sebagaimna hasil penelitian Salmy

37 M.Luthfi Hamidi, Gold Dinar System Moneter Global yang Stabil dan Berkeadilan,(Jakarta; Senayan Abadi Publishing, 2007), h.102-103.

38 Darwis Harahap, Analisis Stabilitas Dinar Emas Dan Dolar AS Dalam Denominasi Rupiah, dalam Jurnal Al-Iqtishad, Vol. VI, No. 2, Juli 2014. 
Edawati Yaacob yang berjudul Study of Implementation Gold Dinar as Currency yang menyatakan bahwa penggunaan emas sebagai mata uang tidak memungkinkan untuk dilaksanakan karena kekurangan dalam penyediaan infrastuktur fisik yakni pasokan emas yang tidak memadai. ${ }^{39}$

Kita ketahui bahwa cadangan emas di dunia ini sebagaimana dilansir ekonomi.kompas.com bahwa dunia hanya memiliki 31,949 ton. ${ }^{40}$ Pertanyaan selanjutnya adalah apakah cadangan emas yang demikian akan mampu memenuhi kebutuhan pembuatan uang emas di dunia? Tentu tidak akan mencukupi. Selanjutnya akan kita telusuri negara mana sebagai pemilik emas terbesar dunia. Dilansir dalam berita yang sama bahwa negara dengan pemilik emas terbesar adalah Amerika serikat dengan 8,133 ton emas, sedangkan Indonesia para peringkat 40 dunia dengan 78,1 ton emas atau $24 \%$ dari total emas dunia. ${ }^{41}$

Jika saat ini Indonesia ingin menerapkan mata uang emas, apakah kepemilikan emas yang ada di Indonesia telah mencukupi? Jawabannya tentu tidak akan mencukupi. Jika tidak mencukupi maka solusinya adalah import emas. Pertanyaan selanjutnya ke negara mana importnya? Maka jawaban paling mungkin adalah ke negara pemilik emas terbesar yakni amerika serikat, Jerman dan IMF. Kita semua tahu bahwa ketiga pemilik emas itu tak satupun negara yang muslim. Maka sama saja kita ingin keluar dari krisis dengan menggunakan mata uang yang tidak tergantung pada naik turunnya mata uang negara lain tetapi kita terjebak pada perdagangan yang juga pada akhirnya tergantung pada negara lain. Ini juga akan menjadi persoalan baru.

Selanjutnya memang benar emas memiliki nilai investasi yang sangat tinggi, oleh karena itu orang lebih suka untuk menyimpan emas untuk investasi dibandingkan untuk bertansaksi. Selain itu emas sebagai mata uang yang digunakan untuk pembayaran atas

39 Salmy Edawati Yaacob, "Study Of Implementation Gold Dinar As Currency", World Applied Sciences Journal 20 (7): h. 1014-1023, 2012.

4010 negara Pemilik emas terbesar di dunia. Lihat http: /ekonomi.kompas.com, terbit pada 12 Juni 2015.

4110 negara Pemilik emas terbesar di dunia. Lihat http: /ekonomi.kompas.com, terbit pada 12 Juni 2015. 
transaksi yang dilakukan, dirasa tidak praktis ketika dibawa, dan dapat memicu kejahatan.

\section{E. DINAR DAN DIRHAM: BENARKAH DAPAT MENJADI SOLUSI KRISIS?}

Krisis ekonomi ${ }^{42}$ merupakan keyword yang menjadi persoalan dalam artikel ini. Setiap orang merasa takut ketika mendengar pernyataan baik yang bisa dipertanggungjawabkan maupun sumber yang hoax, karena yang terbayang adalah menurunnya daya beli masyarakat karena melonjaknya harga kebutuhan pokok masyarakat di pasar. Sehingga setiap individu harus berfikir bagaimana mengelola keuangan yang dimiliki. ${ }^{43}$

Gejala yang umum terjadi ketika sebuah negara mengalami krisis adalah ketidakseimbangan anggaran, ekspansi moneter yang berlebihan, deficit neraca anggaran yang begitu besar, naiknya kecenderungan proteksionis, tidak memadainya bantuan asing, dan kerjasama internasional yang tidak mencukupi. ${ }^{44}$ Dalam pendapat lain dikemukakan bahwa sebab terjadinya krisis ekonomi, dinyatakan oleh ekonom Centre of Reform On Economic (CORE) bahwa ada 2 faktor yang menjadi penyebab terjadinya krisis ekonomi di Indonesia saat ini adalah pertama, tekanan yang dialami oleh negara. Imbas dari perang dagang Amerika-China, sehingga berdampak pada sulitnya modal masuk ke Indonesia. ${ }^{45}$

Kemudian beberapa orang dan kalangan beranggapan bahwa dinar dan dirhamlah solusi atas krisis ini. Dengan tujuan agar mata uang tetap stabil nilainya. Namun pergantian mata uang kertas menjadi emas tidaklah sejalan dengan Umer Chapra salah

\footnotetext{
42 Kondisi dimana suatu negara mengalami perubahan ekonomi yang drastis, yang biasanya ditandai dengan merosotnya nilai tukar mata uang dan melonjaknya harga kebutuhan pokok. Lihat Wikipedia.org

43 Tips yang bisa dilakukan saat krisis yakni, membuat daftar kebutuhan prioritas, lunasi utang segera sebelum krisis, alokasi uang dalam bentuk investasi, pembatasan pengeluaran, miliki banyak uang dalam bentuk tunai, pilih jasa keuangan yang tepat dan terapka gaya hidup hemat. Lihat Nurmayanti, bentengi keuangan dengan 6 cara saat krisis ekonomi, www.m.liputan6.com.

44 lihat Umer Chapra, Sistem Moneter Islam, penerjemah Ihkwan Abidin Basri, judul aslinya Toward a Just Monetary System,( Jakarta: Gema Insani Press, 2000), h.xx

45 Pencegahan krisis ekonomi, berita http:m.kontan.co,id
} 
seorang cendekiawan muslim, ia berpendapat bukan persoalan mata uangnya, tetapi persoalan peran negara dalam mengkontrol langsung harga-harga dan mengeluarkan kebijakan fiskal dan moneter yang sehat. ${ }^{46}$

Jika penggunaan dinar dan dirham menjadi solusi atas krisis yang terjadi, yakni berkaitan dengan ketidakstabilan nilai tukar mata uang maka jika melihat bahwa nilai instrinsik yang terkandung dalam uang dinar dan dirham, maka mungkin saja jika terjadi krisis nilai tukarnya tidak akan berubah. Demikianpun jika mata uang emas tersebut tidak lagi diakui mejadi mata uang maka nilai emas itu sendirilah yang menjadi nilainya. Jika demikian maka solusi atas ketidakstabilan mata uang atas terjadinya krisis dapat dibenarkan.

Namun demikian hal ini akan terbentur dengan ketersediaan emas yang ada, sebagaimana diulas pada pembahasan kelemahan mata uang emas. Ini persoalan baru, keterbatasan emas menyebabkan tidak mungkin menerapkan mata uang ini menjadi alat pembayaran. Kemudian tingkat ketidak amanan mata uang ini juga menjadi salah satu hal yang perlu dipertimbangkan. Bentuk fisik yang memakan tempat, tidak praktis dan mencolok menjadikan kondisi yang memicu kejahatan dan perampokan. Selain itu memasuki dunia digital yang semakin canggih, uang kertaspun lambat laun ditinggalkan, dengan alasan yang sama tidak praktis, memakan tempat, rawan kejahatan. Sekrang telah muncul uang digital yang bentuk fisiknya tidak ada tetapi bisa langsung dimanfaatkan sebagai alat pembayaran transaksi.

\section{F. KESIMPULAN}

Berdasarkan pembahasan di atas, maka dapat disimpulkan bahwa dinar dan dirham tidak secara mutlak dapat menjadi solusi atas krisis yang terjadi di negara ini. Kelebihan dari penggunaan mata uang ini terletak pada nilainya yang tidak tergantung pada

46 Bahwa perekonomian sebuah negara akan selalu tergantung dengan negara lain. Semakin sehat neraca perdagangan sebuah negara -dengan mengedepankan kejujuran dan kebenaran- maka semakin stabil mata uang sebuah mnegara, lihat Umer Chapra, Sistem Moneter Islam, penerjemah Ihkwan Abidin Basri, judul aslinya Toward a Just Monetary System,( Jakarta: Gema Insani Press, 2000), h. 6 
nilai tukar mata uang dari negara lain.

Namun ketersediaan emas yang terbatas menjadi kendala terbesar, kurang praktis, dapat memicu kejahatan, apalagi menghadapi era digitalisasi, demikian pula ketergantungan pada pemilik emas dunia juga tak terelakkan. Selain itu bahwa persoalan krisis bukan semata-mata persoalan mata uang tetapi keseimbangan neraca pembayaran, keterkaitan transaksi luar negeri yang kondisi ekonomi negara lain sebagai mitra. Selanjutnya tidak ada satu negarapun yang masih menggunakan mata uang emas dan perak ini sebagai mata uang resmi di negaranya. Artinya tidak ada role model dalam hal ini. Dengan demikian penulis menyangkal pendapat bahwa dinar dan dirham dapat dijadikan solusi di tengah krisis.[] 


\section{DAFTAR PUSTAKA}

Amalia, Euis, Sejarah Pemikiran Ekonomi Islam dari Masa Klasik Hingga Kontemporer, Jakarta; Pustaka Asatruss, 2005

Bakar, Abu Bin Mohd Yusuf dkk, "Implementation Of The Gold Dinar; Is It The End Of Speculative Measure?”, Journal of Economic Coopration 23, 3 (2002), h. 71-84

Chapra, Umer, Sistem Moneter Islam, penerj. Ihkwan Abidin Basri, judul aslinya Toward a Just Monetary System, Jakarta: Gema Insani Press, 2000

Departemen Pendidikan dan Kebudayaan, Kamus Besar Bahasa Indonesia, Jakarta: Balai Pustaka, 2001

Endriani, Santi, "Konsep Uang: Ekonomi Islam vs Ekonomi Konvensional", Anterior Jurnal, Volume 15 Nomor 1, Desember 2015.

Hamidi, M.Luthfi, Gold Dinar System Moneter Global yang Stabil dan Berkeadilan, Jakarta; Senayan Abadi Publishing, 2007

Harahap, Darwis, Analisis Stabilitas Dinar Emas Dan Dolar AS Dalam Denominasi Rupiah, dalam Jurnal Al-Iqtishad, Vol. VI, No. 2, Juli 2014.

Hasan, Ahmad, Mata Uang Islami: Telaah Komprehensif Sistem Keuangan Islami, Jakarta: Rajagrafindo Persada

http: /ekonomi.kompas.com, terbit pada 12 Juni 2015.

http://wakalaindukbintan.com/jasa-kurir-dibayar-dirham-dimedan

http:m.kontan.co,id

https://finance.detik.com/moneter, Selasa, 16 Feb 2016.

Huda, Nurul, Ekonomi Makro Islam Pendekata Teoritis, Jakarta: Kencana Persada Media Group, 2008

Iqbal, Muhaimin, Dinar The Real Money: Dinar Emas, Uang Dan Investasiku, Jakarta: Gema Insani Press. 
Kamus Bisnis dan Bank, dalam www.mediabpr.com

Karim, Adiwarman A, Ekonomi Makro Islami, Jakarta: PT Rajagrafindo Persada, 2007

Mas'adi, Gufron A., Fiqh Muamalah Kontekstual, Jakarta: Rajagrafindo, 2002

Nasution, Mustofa Edwin, Pengenalan Eklusif Ekonomi Islam, Jakarta: Kencana Prenadi, 2006.

Nurmayanti, bentengi keuangan dengan 6 cara saat krisis ekonomi, www.m.liputan6.com.

Perwataatmadja, "Menggagas Ekonomi Syariah Yang Mantap dengan Peraturan Perundang-undangan yang Baik", Seminar Nasional Hukum Ekonomi, Senat Mahasiswa Fakultas Hukum Universitas Indonesia, tanggal 25-27 Februari 2003, Kampus UI Depok.

Rasyidi, Suherman, Pengantar Teori Ekonomi Pendekatan Kepada Teori Ekonomi Mikro dan Makro, Jakarta: Raja Grafindo Persada, 1999

Saidi, Zaim, Delapan Negara Bagian AS Menuju Berlakukan Uang Emas dan Perak, diakses pada https://zaimsaidi.com/ delapan-negarabagian-berlakukan-emas-perak/.

Setiawan, Deny dkk, "Kekuatan Emas Dan Perak Sebagai Mata Uang Dunia Suatu Studi Pendahuluan”, Jumal Ekonomi, Vol. 18, No. 1 Maret 2010.

Wikipedia.org

Yaacob, Salmy Edawati, "Study Of Implementation Gold Dinar As Currency”, World Applied Sciences Journal 20 (7).

Yusanto, Muhammad Ismail dkk, Dinar Emas, Solusi Moneter, Jakarta: Pirac, Sem Institut, Infid, 2001

Zaiton, Siti binti Moh Dali dkk, implementation gold dinar: is it feasible?, Prosiding Perkem VIII, Jilid 3 (2013) 